\title{
Analisis Keterampilan Gerak dan Ritmik pada Mahasiswa Pendidikan Jasmani
}

\author{
Firdaus Hendry ${ }^{*}$ \\ 1. Universitas Suryakancana \\ *email: firdaus_hendri@unsur.ac.id
}

\begin{abstract}
Abstrak
Penelitian ini bertujuan untuk mengetahui tingkat keterampilan gerak dan ritmik mahasiswa Pendidikan Jasmani FKIP Universitas Suryakancana. Sampel yang diteliti terdiri atas 52 orang mahasiswa Pendidikan Jasmani di lingkungan FKIP UNSUR dengan pengambilan sampel secara total sampling. Data yang diperoleh kemudian di analisis dengan menggunakan analisis statistik deskriptif. Hasil yang diperoleh dari penelitian ini adalah nilai ketukan sampel laki-laki berada pada rerata nilai 77.9, nilai rerata body form 77.8, nilai gerak 78.6, dan penampilan individu sebesar 79.5. Nilai rata-rata penampilan gerak untuk sampel mahasiswa laki-laki adalah sebesar 78.5, sementara nilai ketukan sampel perempuan berada pada rerata nilai 87.5, body form 86.25 , nilai gerak 86.67, dan penampilan individu sebesar 87.5. Nilai rata-rata penampilan gerak keseluruhan untuk sampel mahasiswa perempuan adalah sebesar 87 poin.
\end{abstract}

Kata kunci: aktivitas ritmik, keterampilan, pendidikan jasmani.

\section{PENDAHULUAN}

Sebagai mata kuliah yang relatif baru di dalam kurikulum pendidikan jasmani FKIP Universitas Suryakancana, Pembelajaran Gerak dan Ritmik memiliki tanggung jawab yang relatif besar dimana mata kuliah ini menjadi satu-satunya mata kuliah yang bertanggung jawab untuk memberikan kompetensi gerak dan ritmik kepada para mahasiswa Program Studi Pendidikan Jasmani. Gerak dan ritmik selama ini telah menjadi dua hal yang saling berpadu dalam aktifitas pendidikan jasmani dalam kurikulum sekolah, mulai dari tingkat dasar hingga menengah atas, namun demikian porsi yang diberikan untuk aktivitas tersebut masih relatif sedikit dibandingkan aktivitas gerak yang lainnya. Aktivitas gerak yang dipadukan dengan irama atau ritme tersebut dapat kita lihat dalam berbagai aktivitas di lingkungan sekolah baik dalam koridor pelajaran pendidikan jasmani maupun diluar konteks kePenjasan.

Dalam ruang lingkup pendidikan jasmani, aktivitas gerak dan ritmik dapat kita lihat dalam aktivitas senam irama, tarian gerak tradisional, dsb., sedangkan aktivitas gerak dan ritmik yang biasa kita lihat di luar ruang lingkup Pendidikan Jasmani seperti; aktivitas baris-berbaris, upacara, pramuka, dsb. Gerak memiliki arti perpindahan tempat dari satu titik ke titik lain, dan ritmik secara sederhana diartikan sebagai keteraturan dalam irama. Aktivitas fisik sendiri memiliki keterkaitan yang sangat erat dengan kesehatan mental yang dimiliki seseorang (Carless \& Douglas, 2010). 


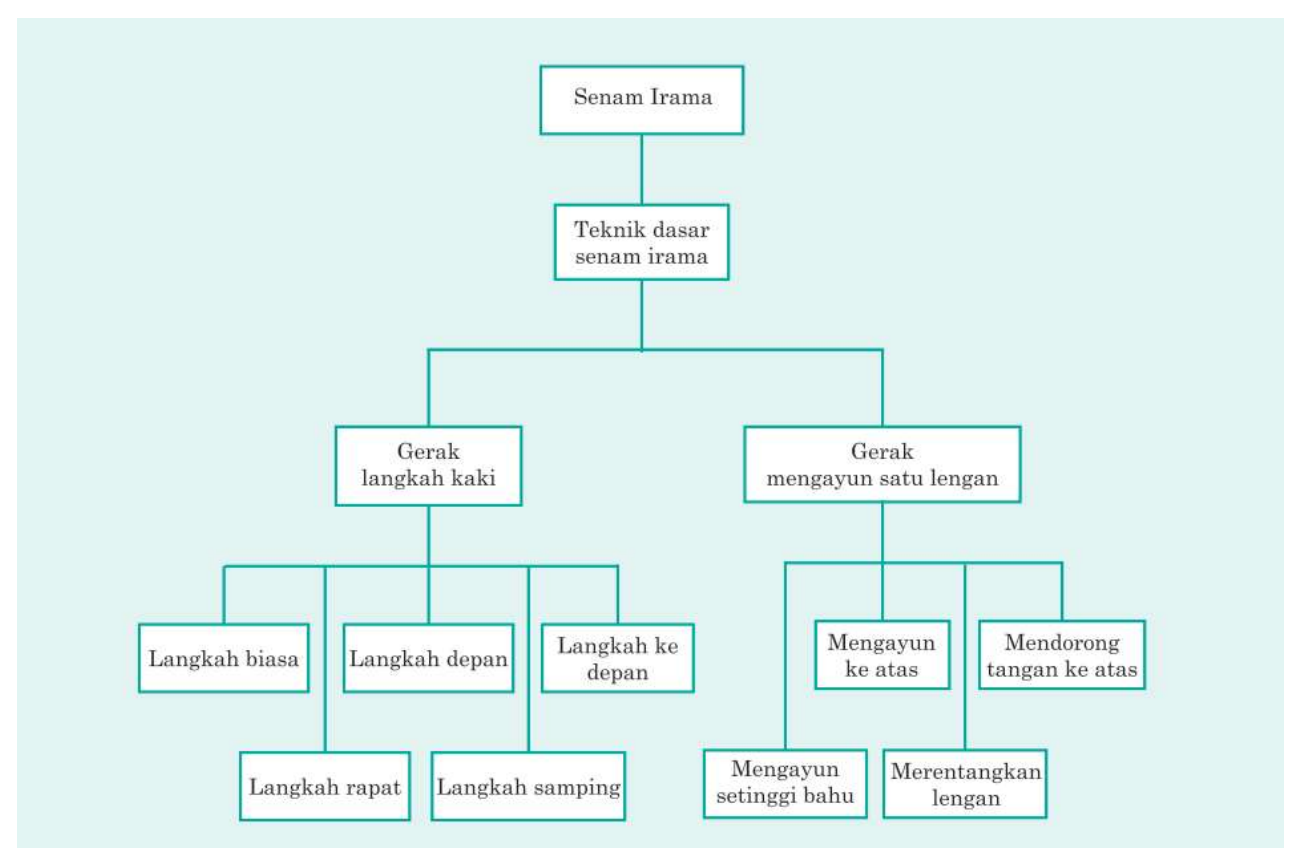

Peta konsep aktivitas ritmik dasar (Depdiknas, 2010)

Senam irama sendiri dalam kurikulum mata kuliah senam menjadi salah satu cabang dari pada olahraga senam secara keseluruhan, yang bersama-sama dengan cabang senam yang lain menjadi bahan kompetensi yang diberikan kepada para mahasiswa Pendidikan Jasmani. Hal ini berkaitan dengan perkembangan usaha aktivitas ritmik di masyarakat telah berkembang dengan demikian luas dan pesat. Kegiatan aktivitas ritmik yang popular di masyarakat sangatlah bervariasi, mulai dari Senam Kesegaran Jasmani (SKJ) untuk anak sekolah, senam aerobik, hingga aktivitas ritmik yang lainnya. Senam aerobik merupakan salah satu bagian dari senam irama. Senam aerobik secara umum dapat dibagi menjadi dua macam, sebagai berikut, yakni; Low impact aerobic dimana gerakan kaki pesenam tidak pernah meninggalkan lantai, dan High impact aerobic adalah gerakan pesenam yang meninggalkan lantai, banyak lompat, jingkrak, dan bermacam-macam lari (Aan \& Teguh, 2010).

Senam SKJ sendiri memiliki sejarah yang panjang dalam keterlibatannya terhadap ruang lingkup Pendidikan jasmani dan sekolah pada umumnya, dimana sudah sejak lama senam SKJ tersebut menjadi kegiatan utama yang rutin dilakukan setiap hari jumat pagi di sekolah-sekolah terutama sekolah Negeri. Hal ini membuktikan tingkat kesadaran untuk melibatkan aktivitas ritmik dasar di tingkat sekolah merupakan hal yang sangat penting, dan selama ini sudah dilaksanakan dalam jenjang Pendidikan dasar. Jika dilakukan dengan baik dan porsi yang tepat senam SKJ sendiri memiliki kontribusi yang baik bagi kebugaran tubuh (Nur Latifah, 2019) 




Peta konsep aktivitas ritmik lanjutan (Depdiknas, 2010)

Berkaitan dengan penelitian yang dilakukan pada kesempatan kali ini, gerak yang dimaksud adalah gerak yang berkaitan dengan aktivitas pendidikan jasmani atau olahraga. Ritmik sendiri berasal dari kata Rhythm dari Bahasa inggris yang berarti ketukan atau irama. Respon terhadap ritme berarti bahwa respon terhadap elemen irama yang dihasilkan oleh musik, dimana tempo menjadi irama yang ada dalam musik dalam ukuran Beat Per Minute (BPM), yang mana diidentifikasikan sebagai karakteristik utama dalam musik yang memunculkan respon fisik. (Benham \& Benham, 2014)

Gerak didefinisikan berdasarkan bidang gerak dimana gerak tersebut dilakukan. Menurut ilmu anatomi, gerak tubuh terjadi diakibatkan oleh adanya system gerak tubuh dimana otot-otot tubuh menarik bagian tulang lain sehingga terjadi gerakan bagian tubuh tertentu (Marieb \& Hoehn, n.d.). Tubuh memiliki tiga macam bidang gerak dengan arah yang berlainan, yakni bidang gerak horizontal, vertical depan belakang, dan vertikal kiri-kanan. Menurut ilmu kinesiology dan biomekanika, bidang gerak di bagi menjadi tiga yakni bidang gerak Transversal yang membelah tubuh menjadi bagian atas (Superior) dan bawah (Inferior), bidang gerak Frontal yang membagi dimensi tubuh menjadi bagian depan (Anterior) dan belakang (Posterior), serta bidang Sagital yang membagi dimensi tubuh menjadi bidang tengah (Medial) dan luar (Lateral) (Milner, 2008).

Gerak sendiri bila dilihat dari bidang geraknya terdiri atas beberapa macam. Untuk mudahnya gerakan dapat di kategorikan menjadi beberapa macam seperti gerak ke arah depan, belakang, samping kiri, samping kanan, atas dan bawah, sedangkan menurut ilmu kinesiology sendiri, gerakan-gerakan tersebut disebut menjadi; Anterior-posterior, medial-lateral, dan superior-inferior.

Gerak yang dimaksud dalam penelitian ini adalah gerak-gerak yang memiliki karakteristik yang ditujukan sesuai dengan tujuan pendidikan jasmani dan olahraga, yakni:

a. Bertujuan pendidikan. 
b. Memiliki karakteristik yang membangun kapasitas fisik dan mental.

c. Bersifat menyenangkan dan menghibur (Satu, 2010)

Salah satu tujuan daripada Pendidikan Jasmani sendiri adalah dalam rangka memberikan kemampuan dasar para peserta didik dalam memiliki keinginan pola hidup sehat, dan salah satu kegiatan yang dapat dilakukan berkaitan dengan tujuan tersebut adalah dengan menari atau dance, atau kegiatan lainnya yang bersifat ritmik (Bajek et al., 2015).

Berdasarkan tujuan-tujuan yang telah disebutkan diatas maka gerak yang dimaksud untuk tujuan penelitian ini adalah gerak-gerak memiliki variasi tertentu supaya tujuan tersebut tercapai. Gerak-gerak yang dilakukan oleh para sampel penelitian ini dipadukan dengan irama yang berasal dari sumber yang sederhana seperti ketukan tangan atau hitungan suara mulut, hingga irama yang dikeluarkan oleh sumber perangkat audio. Bagi anak-anak dan usia remaja, melakukan gerakan yang dibarengi dengan musik dapat membangkitkan semangat dan rasa senang dan termotivasi. Aktivitas fisik dengan menggunakan musik sendiri merupakan salah satu aktivitas yang sangat dianjurkan untuk dilakukan pada anak-anak usia dini. Salah satu cara yang dapat dilakukan di sekolah berkaitan dengan kesehatan peserta didiknya adalah; Meningkatkan porsi aktifitas fisik bagi anak-anak, menggabungkan musik kedalam aktivitasaktivitas tersebut, memilih lagu dan musik yang sesuai dengan perkembangan anak didik, menggunakan alat atau instrument yang sederhana dalam aktivitas fisik, melakukan aktivitas fisik dalam ruangan yang cukup luasnya, mengundang para orang tua untuk turut serta dalam aktivitas tersebut, memilih lagu dan meminta anak agar melakukan gerakan sesuai dengan lirik lagu tersebut. (Izumi-Taylor, Morris, Meredith, \& Hicks, 2012).

Hal tersebut diatas menjadi satu diantara banyak keterampilan yang harus dimiliki oleh para lulusan Pendidikan jasmani untuk dapat diterapkan di sekolah tempat mereka mengajar di kemudian hari. Maka demikian dalam perkuliahan aktfvitas gerak dan ritmik sendiri, para mahasiswa dituntut untuk dapat melaksanakan tugas gerak dengan birama secara baik dan tepat. Terdapat satu komponen yang menjadi penilaian utama bagaimana penampilan gerak dan ritmik tersebut dilakukan oleh para sampel, yakni bentuk postur tubuh ketika gerak tersebut dilaksanakan. Postur sendiri dapat diartikan sebagai posisi relatif tubuh, biasanya diasosiasikan dengan posisi tubuh statis atau pada saat kondisi diam. Postur tubuh dapat diartikan juga sebagai posisi tubuh berkaitan dengan posisi nya terhadap lantai tempat pijakan apakah berdiri tegak, membungkuk, berjongkok, berbaring, dsb. (Australian Sports Commision, 2007). Postur tubuh yang baik dapat terlihat dari bentuk tubuh yang simetris pada bidang sagital yang membagi tubuh menjadi dua bagian kanan dan kiri, dan juga pada pusat masa tubuh yang berada tepat berada di tengah-tengah apabila ditarik garis lurus dari kepala hingga telapak kaki.

Berdasarkan masalah yang telah dikemukakan di atas, maka tujuan yang hendak dicapai dalam penelitian ini adalah sebagai berikut:

1. Untuk mengetahui tingkat keberhasilan mahasiswa dalam menyelesaikan beban perkuliahan Pembelajaran Gerak dan Ritmik?

2. Untuk mengetahui analisa deskriptif kemampuan mahasiswa dalam Pembelajaran Gerak dan Ritmik?

3. Untuk mengetahui tingkat kemampuan mahasiswa dalam membuat dan menampilkan karya gerak dan ritmik? 
Adapun manfaat atau kegunaan penelitian yang penulis harapkan adalah sebagai berikut:

1. Kegunaan Teoritis

Dengan penelitian ini diharapkan dapat memberikan informasi awal mengenai kemampuan mahasiswa dalam memahami dan mempraktekkan keterampilan gerak dan ritmik dalam ranah pendidikan jasmani.

2. Kegunaan Praktis

a. Bagi Institusi

Memberikan masukan yang positif bagi institusi pendidikan terutama para pendidik dalam mempersiapkan kompetensi keterampilan gerak dan ritmik pada mahasiswa Pendidikan Jasmani FKIP UNSUR.

b. Bagi peneliti

Diharapkan dapat menjadi bahan rujukan untuk penelitian lebih lanjut bagi perkembangan proses belajar mengajar pendidikan jasmani, khususnya mata kuliah Pembelajaran Gerak dan Ritmik.

\section{Metode}

Penelitian ini dilakukan dengan menggunakan instrumen deskriptif dengan teknik dengan cara mengumpulkan data yang diperoleh untuk kemudian mengukur dan mencatat hasil dari pengukuran yang benar dari hasil penilaian mahasiswa yang diberikan perlakuan metode pembelajaran yang bervariasi tergantung daripada karakteristik pembelajaran tersebut berlangsung. Adapun variabel yang diteliti dalam penelitian ini adalah tingkat keterampilan mahasiswa dalam aktivitas gerak dan ritmik, sedangkan sampel yang digunakan adalah seluruh mahasiswa mata kuliah Pembelajaran Gerak dan Ritmik Program Studi Pendidikan Jasmani FKIP UNSUR 2018 sebanyak 52 orang yang diambil dengan menggunakan instrumen total sampling, dimana seluruh populasi yang dituju, dijadikan sebagai sampel penelitian secara acak. Penelitian ini dilaksanakan pada Area Gedung Aula Fakultas Keguruan dan Ilmu Pendidikan, Universitas Suryakancana. Pada bulan Juni 2018

Teknik pengumpulan data yang diambil pada konstelasi penelitian adalah data-data variabel yang menunjang kualitas keterampilan gerak mahasiswa mata kuliah Pembelajaran Gerak dan Ritmik. Pengumpulan data dilakukan pada akhir proses mata kuliah Pembelajaran Gerak dan Ritmik dimana komponen yang diambil datanya adalah; 1) Nilai Ketukan, 2) Body Form, 3) Nilai Gerakan, 4) Nilai Penampilan, 5) Nilai rata-rata, 6) Nilai Musik, 7) Nilai Koreografi, 8) Nilai Video Kelompok. Data-data variabel yang dikumpulkan tersebut menjadi tolak ukur tingkat keterampilan mahasiswa dalam mengikuti proses perkuliahan dan juga menjadi komponen penilaian praktikum pada akhir semester proses pembelajaran. Tingkat keterampilan para mahasiswa dalam praktek pembelajaran gerak dan Ritmik sendiri merupakan akumulasi dari variabel-variabel yang datanya diambil pada proses pengambilan data tersebut dilaksanakan.

Instrumen Penelitian merupakan variabel pemahaman mahasiswa terhadap langkahlangkah keterampilan gerakan senam dasar dinilai dengan metode survei dengan instrumen 
rubrik penilaian gerak dan ritmik yang berisi mengenai poin-poin komponen keterampilan kompetensi beban perkuliahan pembelajaran gerak dan ritmik.

Analisis data penelitian yang telah terkumpul diolah dan dianalisis dengan metode statistik, antara lain dilakukan penghitungan nilai rata-rata, standar deviasi, pemusatan dan penyebaran data.

\section{Hasil}

Menurut hasil analisa deskriptif, nilai minimal yang didapat oleh sampel penelitian dengan jenis kelamin laki-laki adalah 67,5 dan nilai tertinggi pada skor maksimal 97.5. Sementara nilai ketukan sampel laki-laki berada pada rerata nilai 77.9 , nilai rerata body form 77.8 , nilai gerak 78.6, dan penampilan individu sebesar 79.5. Nilai rata-rata penampilan gerak untuk sampel mahasiswa laki-laki adalah sebesar 78.5.

Hasil nilai minimal yang didapat oleh sampel penelitian dengan jenis kelamin perempuan adalah 67,5 dan nilai tertinggi pada skor maksimal 100. Sementara nilai ketukan sampel perempuan berada pada rerata nilai 87.5 , body form 86.25 , nilai gerak 86.67 , dan penampilan individu sebesar 87.5. Nilai rata-rata penampilan gerak keseluruhan untuk sampel mahasiswa perempuan adalah sebesar 87 poin.

\section{Kesimpulan}

Berdasarkan Analisa statistika deskriptif yang dilakukan terhadap hasil kuesioner data pemahaman gerakan keterampilan senam dasar yang dilakukan pada mahasiswa Pendidikan Jasmani FKIP Universitas Suryakancana, dapat di simpulkan beberapa hal sebagai berikut.

1. Jumlah perbandingan jumlah sampel laki-laki dan perempuan adalah 88.5 persen berbanding dengan 11.5 persen. Rerata hasil penelitian mengenai variable gerak dan ritmik secara individu untuk perempuan lebih baik dibandingkan hasil sampel laki-laki dengan perbandingan sebesar 87 poin untuk rerata nilai penampilan keseluruhan untuk mahasiswa perempuan dan 78.5 poin untuk hasil penampilan keseluruhan mahasiswa laki-laki.

2. Penelitian ini mengungkap keterampilan rerata yang dimiliki oleh mahasisa berjenis kelamin perempuan lebih baik dibandingkan mahasiswa laki-laki dengan selisih ratarata 8.5 poin dalam skala 100 .

\section{Saran}

1. Diperlukan beberapa penelitian lain yang menunjang untuk dapat mengungkap komponen yang mungkin dapat berpengaruh dalam hasil penelitian ini, seperti komponen antropometri dan biomotorik para sampel mahasiswa.

2. Hasil penelitian ini dapat menjadi awal daripada penelitian lain yang relevan berkaitan dengan penelaahan mengenai keterampilan gerak dan ritmik.

\section{Referensi}

Aan, S. W., \& Teguh, S. (2010). Pendidikan Jasmani Olahraga dan Kesehatan. In Jakarta: Pusat Perbukuan Kementerian Pendidikan Nasional. 
Australian Sports Commision. (2007). Move to Dance.

Bajek, M., Richards, K. A. R., Ressler, J., Bajek, M., Richards, K. A. R., \& Ressler, J. (2015). Benefits of Implementing a Dance Unit in Physical Education Benefits of Implementing a Dance Unit in Physical Education. (September). https://doi.org/10.1080/08924562.2015.1066613

Benham, L. K., \& Benham, L. (2014). The Effects of Music on Physical Activity Rates of Junior High Physical Education Students.

Carless, D., \& Douglas, K. (2010). Sport and Physical Activity for Mental Health. In Mental Health and Physical Activity (Vol. 3). https://doi.org/10.1016/j.mhpa.2010.08.001

Depdiknas. (2010). PENJASORKES Kelas X.

Izumi-Taylor, S., Morris, V. G., Meredith, C. D., \& Hicks, C. (2012). Music and Movement for Young Children's Healthy Development. Dimensions of Early Childhood, 40(2), 3340. Retrieved from http://search.proquest.com.ezproxy.library.yorku.ca/docview/1140135305?accountid=15 182\%5Cnhttp://sfx.scholarsportal.info/york?url_ver=Z39.882004\&rft_val_fmt=info:ofi/fmt:kev:mtx:journal\&genre=article\&sid=ProQ:ProQ:ericshel $1 \&$ atitle $=\overline{\text { Music }}+$ and + Movement + for + Yo

Marieb, E. N., \& Hoehn, K. (n.d.). Human Anatomy \& Physiology.

Milner, C. E. (2008). Functional Anatomy for sport and exercise.

Nur Latifah, I. (2019). PENGARUH PEMBERIAN SENAM KEBUGARAN JASMANI (SKJ) 2018 TERHADAP PENINGKATAN VO2 MAKS PADA SISWI SMA MTA SURAKARTA. UMS Surakarta.

Satu, T. (2010). Pendidikan jasmani. 